\title{
New remarkable bat records in Hoang Lien Son mountain range, northern Vietnam
}

\author{
Sergei V. Kruskop \& Anton V. Shchinov
}

\begin{abstract}
During a short-term survey, fifteen bat species were recorded in the north-east part of Hoang Lien Son mountain range, Tonkin, Vietnam; some of these findings are of particular zoogeographic interest. The first confirmed record of Barbastella from Vietnam was made; the specimens morphologically resemble $B$. darjelingensis, differing slightly in coloration from Indian and Central Asian forms. The specimen tentatively identified as Hypsugo cf.joffrei may represent the first record of the species outside its terra typica. Harpiola isodon is reported for the second time from Vietnam; its new capture site is situated half-way the between previous known location in Ngoc Linh and terra typica in Taiwan. Records of Murina cf. harpioloides, Hypsugo cadornae and Thainycteris aureocollaris represent Vietnamese range extensions for these species; among them, the collecting site of $M$. cf. harpioloides is very remote from previously known location. The local bat community seems to be a rich mix of Malayan, Indo-Himalayan and even Palaearctic faunal elements.
\end{abstract}

KEY WORDS: bats, Barbastella, Hypsugo, Harpiola, South-East Asia, Indochina.

SergeiV.Kruskop [kruskop@zmmu.msu.ru], Zoological Museum, Moscow State University, ul. Bolshaya Nikitskaya 6, Moscow 125009, Russia; Anton V. Shchinov [schinov_anton@mail.ru], Joint Vietnam-Russian Tropical Research and Technological Centre, Nguyen Van Huyen, Nghia Do, Cau Giay, Hanoi, Vietnam.

\section{Новые примечательные находки рукокрылых на горном хребте Хоанг Лиен Шон, северный Вьетнам}

\section{С.В. Крускоп, А.В. Щинов}

\begin{abstract}
РЕЗЮМЕ. Во время краткого полевого исследования пятнадцать видов летучих мышей были обнаружены в северо-восточной части хребта Хоанг Лиен Шон, Тонкин, Вьетнам. Поимка широкоушки (Barbastella) представляет собой первую документированную находку этого рода во Вьетнаме. Пойманные широкоушки наиболее сходны с $B$. darjelingensis, хотя и отличаются по окраске от экземпляров из Индии и Средней Азии. Экземпляры, предварительно определенные как Hypsugo cf. joffrei, вероятно, представляет собой первую находку вида за пределами типового локалитета. Harpiola isodon обнаружена во Вьетнаме второй раз, и новая точка находки лежит между ранее известной точкой в Нгоклине и типовым местонахождением на Тайване. Находки Murina cf. harpioloides, Hypsugo cadornae и Thainycteris aureocollaris представляют собой новые места обитания этих видов во Вьетнаме; в случае $M$. cf. harpioloides новая точка поимки весьма значительно удалена от известной прежде. В целом, локальное сообщество рукокрылых представляется смесью малайских, индо-гималайских и даже палеарктических элементов.
\end{abstract}

КЛЮЧЕВЫЕ СЛОВА: рукокрылые, широкоушка, кожановидные нетопыри, гарпиола, Юго-Восточная Азия, Индокитай.

\section{Introduction}

Hoang Lien Son mountain range is situated on the very north of Tonkin (Northern Vietnam). Situating relatively far from the supposed border between Palaearctic and Indomalayan zoogeographical regions, it actually represents an extension of the mountainous ranges, which form this border westward from Indochina (Corbet \& Hill, 1992; Hoffmann, 2001) and thus could serve as 'bridges' for Palaearctic faunal elements. This, together with the high altitudinal variation, suggests a diverse fauna containing a mix of Malayan, Indo-Himalayan and even Palaearctic species.
Zoological investigation of this area started in the early 1900-th (Rozhnov, 1998), and the first complete review of local mammalian fauna was produced by Osgood (Osgood, 1932). Later one bat species was described as new on the basis of same collections, namely Rhinolophus paradoxolophus (originally in separate genus Rhinomegaphyllus) (Bouret, 1951). Recent unpublished report prepared by "Frontier" environmental exploration company lists 17 bat species including such remarkable record as Myotis chinensis (Tordoff et al., 1999). In the recent checklist of Vietnamese mammalian fauna (Dang Ngoc Can et al., 2008), 26 bat species from five families are recognized for Hoang 
Table 1. List of bat species reported for Hoang Lien Son. 1 - this survey; 2 - Dang Ngoc Can et al., 2008; 3 - Tordoff et al., 1999; 4 - Rozhnov et al., 2008; * — only visual/aural record.

\begin{tabular}{|c|c|c|c|}
\hline & Species & source & comments \\
\hline \multicolumn{4}{|c|}{ Pteropodidae } \\
\hline 1. & Rousettus leschenaulti (Desmarest, 1820) & $1 *, 2,3$ & \\
\hline 2. & Cynopterus sphinx (Vahl, 1797) & $2,3,4$ & \\
\hline 3. & Cynopterus brachyotis (Müller, 1838) & 2 & \\
\hline 4. & Sphaerias blanfordi (Thomas, 1891) & 4 & \\
\hline 5. & Megaerops niphanae Yenburta, Felten, 1983 & 2,3 & \\
\hline \multicolumn{4}{|c|}{ Hipposideridae } \\
\hline 6. & Aselliscus stoliczkanus (Dobson, 1871) & $1,2,3$ & \\
\hline 7. & Coelops frithii Blyth, 1848 & 2 & \\
\hline 8. & Hipposideros armiger (Hodgson, 1835) & 2 & \\
\hline 9. & Hipposideros larvatus (Horsfield, 1823) & 2 & \\
\hline 10. & Hipposideros pomona Andersen, 1918 & 2,3 & \\
\hline 11. & Hipposideros pratti Thomas, 1891 & 2 & \\
\hline \multicolumn{4}{|c|}{ Rhinolophidae } \\
\hline 12. & Rhinolophus affinis Horsfield, 1823 & $1,2,3$ & \\
\hline 13. & Rhinolophus lepidus Blyth, 1844 & 2,4 & Could be misidentified with $R$. pusillus. \\
\hline 14. & Rhinolophus macrotis Blyth, 1844 & $1,2,3$ & \\
\hline 15. & Rhinolophus marshalli Thonglongya, 1973 & 2 & \\
\hline 16. & Rhinolophus paradoxolophus (Bourret, 1951) & 2,3 & \\
\hline 17. & Rhinolophus pearsonii Horsfield, 1851 & 2,3 & \\
\hline 18. & Rhinolophus thomasi Andersen, 1905 & 2 & \\
\hline 19. & Rhinolophus sinicus Andersen, 1905 & 2,3 & Often mentioned as $R$. rouxii $\mathrm{s}$. 1 . \\
\hline \multicolumn{4}{|c|}{ Vespertilionidae } \\
\hline 20. & Harpiocephalus harpia (Temminck, 1840) & 4 & \\
\hline 21. & Kerivoula hardwickii (Horsfield, 1824) & 4 & \\
\hline 22. & Harpiola isodon Kuo, Fang, Csorba, Lee, 2006 & 1 & \\
\hline 23. & Murina cyclotis Dobson, 1872 & 4 & \\
\hline 24. & Murina huttoni (Peters, 1872) & 1,4 & \\
\hline 25. & Murina cf. harpioloides Kruskop, Eger, 2008 & 1 & \\
\hline 26. & Myotis chinensis (Tomes, 1857) & 3 & \\
\hline 27. & Myotis laniger (Peters, 1871) & $1,2,3$ & $\begin{array}{l}\text { Also mentioned erroneously as } M \text {. } \\
\text { daubentonii. }\end{array}$ \\
\hline 28. & Myotis montivagus (Dobson, 1874) & 1 & \\
\hline 29. & Myotis ?adversus (Horsfield, 1824) & 2 & $\begin{array}{l}\text { Doubtful record, probably result of } \\
\text { misidentification. }\end{array}$ \\
\hline 30. & Myotis siligorensis (Horsfield, 1855) & $1,2,3$ & \\
\hline 31. & Barbastella cf. darjelingensis (Hodgson, 1855) & 1 & \\
\hline 32. & Pipistrellus coromandra (Gray, 1838) & 1,2 & \\
\hline 33. & Hypsugo cadornae (Thomas, 1916) & 1 & \\
\hline 34. & Hypsugo cf. joffrei (Thomas, 1915) & 1 & \\
\hline 35. & Scotomanes ornatus (Blyth, 1851) & 2,3 & \\
\hline 36. & Thainycteris aureocollaris Kock, Storch, 1996 & 1 & \\
\hline 37. & Tylonycteris pachypus (Temminck, 1840) & 4 & \\
\hline \multicolumn{4}{|c|}{ Miniopteridae } \\
\hline 38. & Miniopterus fuliginosus (Hodgson, 1835) & 1 & $\begin{array}{l}\text { Previously was erroneously mentioned as } \\
\text { M. schreibersi. }\end{array}$ \\
\hline \multicolumn{4}{|c|}{ Molossidae } \\
\hline 39. & Tadarida $\mathrm{sp}$. & $1 *$ & \\
\hline
\end{tabular}

Lien Son. Kuznetsov and Rozhnov (Kuznetsov \& Rozhnov, 1998) mentioned four additional species on the basis of unconfirmed published data. Two of them, Harpiocephalus harpia and Kerivoula picta, were previously reported for Lao Cai province but not exactly for Hoang Lien Son (Dang Huy Huynh et al., 1994). Records of Rhinolophus cornutus in Vietnam are doubtful and very probably are based on misidentified $R h$. pusillus or other similar species. Finally, the report of $R h$. luctus from Hoang Lien Son is not supported by any material and absent in the latest checklists.

Investigations in Van Ban district, in the southern part of Hoang Lien Son, held by Vietnam-Russian Tropical Centre, produced several new records and, amongst other findings, documented the presence of two Murina species, Kerivoula hardwickei and Sphaerias blanfordi 
and confirmed occurrence of the Harpiocephalus in Hoang Lien Son (Rozhnov et al., 2008). Thus, even excluding unconfirmed records, its local bat faunal list contains over 30 species (Tab. 1). Despite this, the survey of the bat communities of Hoang Lien Son is far from completion. Its mosaic landscapes and significant elevation gradients lead to expect the occurrence of additional species.

During our survey in the vicinity of Sa Pa in 20092010, we confirmed and clarified several earlier bat records and found at least six bat species not previously known to Hoang Lien Son area.

\section{Material and methods}

Special short field survey focused on bats was conducted from 5 to 20 of May in 2010. Also some bats were captured and recorded in the ranks of general small mammal assessment during summer, 2009. Most of bat records were made in the vicinity of Tram Ton forest station, $6 \mathrm{~km} \mathrm{NW}$ from town of Sa Pa (Chapa), Lao Cai Province $\left(22^{\circ} 21^{\prime} \mathrm{N}, 103^{\circ} 46^{\prime} \mathrm{E}\right)$, at the elevation range of 1850-2000 $\mathrm{m}$ a.s.l. Also some bat records were made south from $\mathrm{Sa} \mathrm{Pa}$, in Cat Cat village, at the elevation of about $1250 \mathrm{~m}$ ASL.

Observations were conducted visually with the help of electric head lamps and spotlights, and acoustically by the use of narrow-band heterodyne ultrasound detector D100 (Pettersson Elektronik AB, Sweden). Taking into account local weather conditions resulted into bat activity pattern, observations were held in the thirst half of night time, from the sunset till approximately $22^{00}$ $\mathrm{PM}$, and in the early morning, from $4^{00} \mathrm{AM}$ to sunrise. Bats were captured alive by hand net or flap-trap (Borissenko, 1999) and by the standard technique of crossing supposed flying paths by mist-nets (size 10×4 m) (Kunz \& Kurta, 1990; Borissenko \& Kruskop, 2003).

A standard set of external measurements (head and body length, tail length, hind foot length (with and without claws), ear length, tragus/antitragus length, tibia length and forearm length) was taken using vernier calipers. Weight recorded using Pesola spring balances to the nearest $0.1 \mathrm{~g}$. Selected specimens (from one to four) of each species were taken as vouchers for further comparison with museum material to ensure the proper identification as most species are notoriously impossible to identify in the field. Voucher specimens transferred to the Zoological Museum, Moscow State University (ZMMU, Moscow), and are preserved in 70\% ethanol. Tissue samples for genetic studies were taken from fresh specimens and stored in $96 \%$ ethanol.

\section{Results}

During our brief survey presence of fifteen bat species were revealed and supported by vouchers, including some remarkable records in the content of the whole Indochinese fauna. Actual richness of the local bat community should be higher since some observed taxa

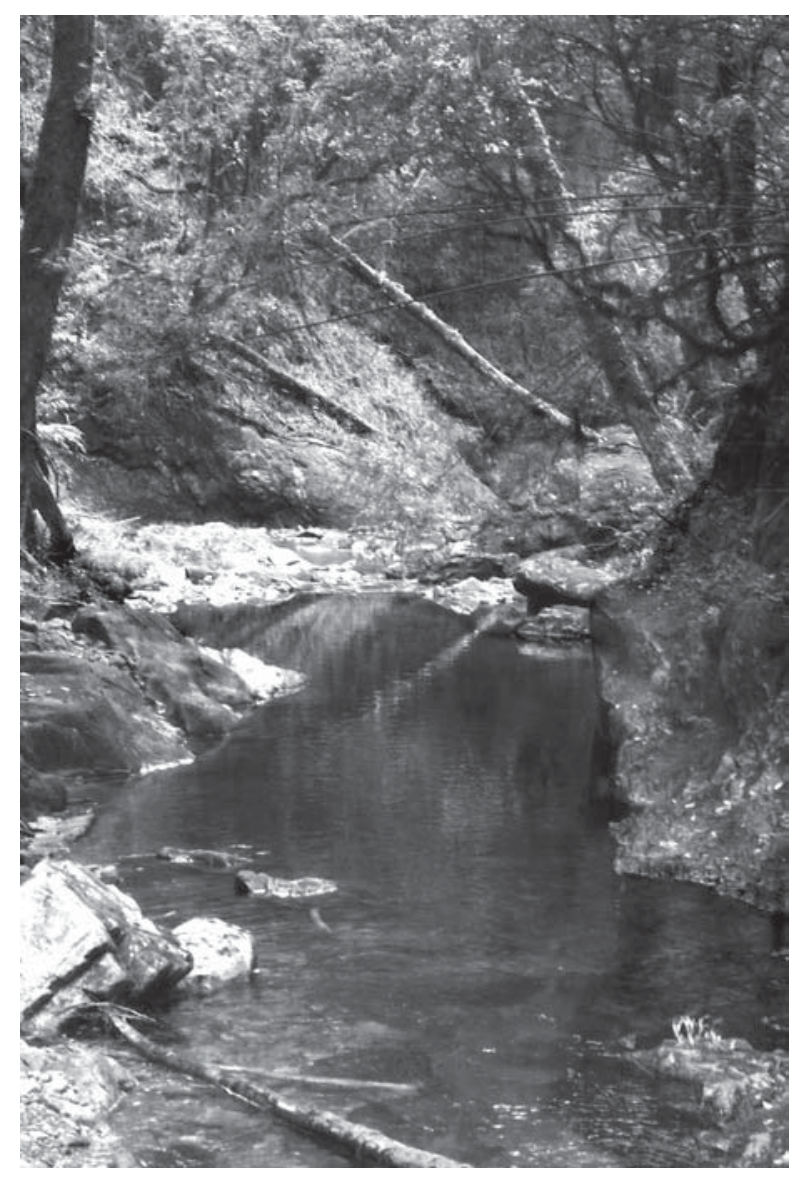

Figure 1. Backwater on the Suoi Vang Stream - foraging biotope for Barbastella $\mathrm{cf}$. darjelingensis, Harpiola isodon, Murina sp. and Rhinolophus affinis.

were not confirmed by captured individuals. These data suggest that the bat diversity and density comparable to that of lowland forested areas of Southern Vietnam known by their rich bat faunas (Hendrichsen et al., 2001; Borissenko \& Kruskop, 2003; Pollet \& Ling, 2004; Nguyen Truong Son et al., 2009).

The most remarkable results of the survey are the finding of three species: Barbastella $\mathrm{cf}$. darjelingensis, Harpiola isodon and Hypsugo cf. joffrei in Northern Vietnam.

An adult non-breeding female of barbastelle was captured by flap trap over the Suoi Vang stream at the elevation of about $2000 \mathrm{~m}$ a.s.l. on 6 May. The animal was foraging over a small backwater area (Fig. 1), moving in a highly maneuverable manner at about 0.5 to 2 meters above the water surface. A male (full-grown but probably young, Fig. 2) was captured about thirty meters from the previous place, over the same stream, on 14 May. The Suoi Vang stream in the capture site has from one and half to six meters in width and consists of alternating backwaters and stony shallows; it goes through the relatively deep ravine with slopes covered with variably disturbed evergreen forest. Both animals were captured in late evening hours in the high 


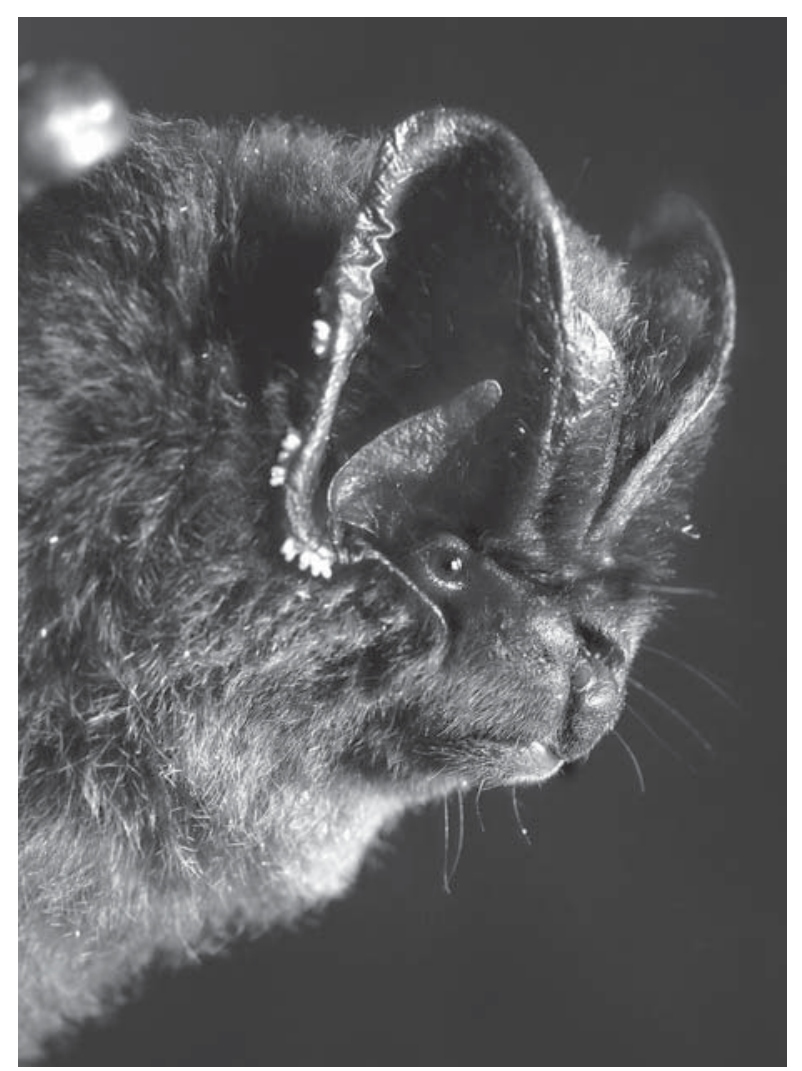

Figure 2. Full-growth male of Barbastella cf. darjelingensis.

darkness, enforced by ravine slopes and forest cover. Aside from captured individuals we did not observed barbastelles in the survey area. Barbastella (tentatively, B. darjelingensis) was reported from Laos and south China and it was supposed that it is also inhabits northern Vietnam (Francis, 2008). Our record is the first confirmed occurrence of the genus in Hoang Lien Son area and in Vietnam on the whole.

One subadult male of Harpiola isodon was captured by a mist-net set across the stream, at the same site as Barbastella on May, 6 in the late evening (Fig. 3). On 8 May an adult female was caugth at the same place and on 10 and 13 May two more subadult males were captured. Animal foraged over the stream backwaters and shallows, flying at about $0.2-2$ meters above the water or ground. Observed flight pattern was variably fast, dodged and very maneuverable. Several times throughout the survey period animals of similar size and with same flight pattern were observed over the Suoi Vang both upstream and downstream the waterfall; however Harpiola seems to be almost indistinguishable in flight from the similar sized Murina species. The only captured female was lactating. Simultaneous presence of recently weaned individuals suggests that Harpiola in Hoang Lien Son may have a bi- or even polymodal breeding cycle (Happold \& Happold, 1990).

The first Hypsugo cf.joffrei (adult male, Fig. 4) was captured in the early morning hours (about an hour

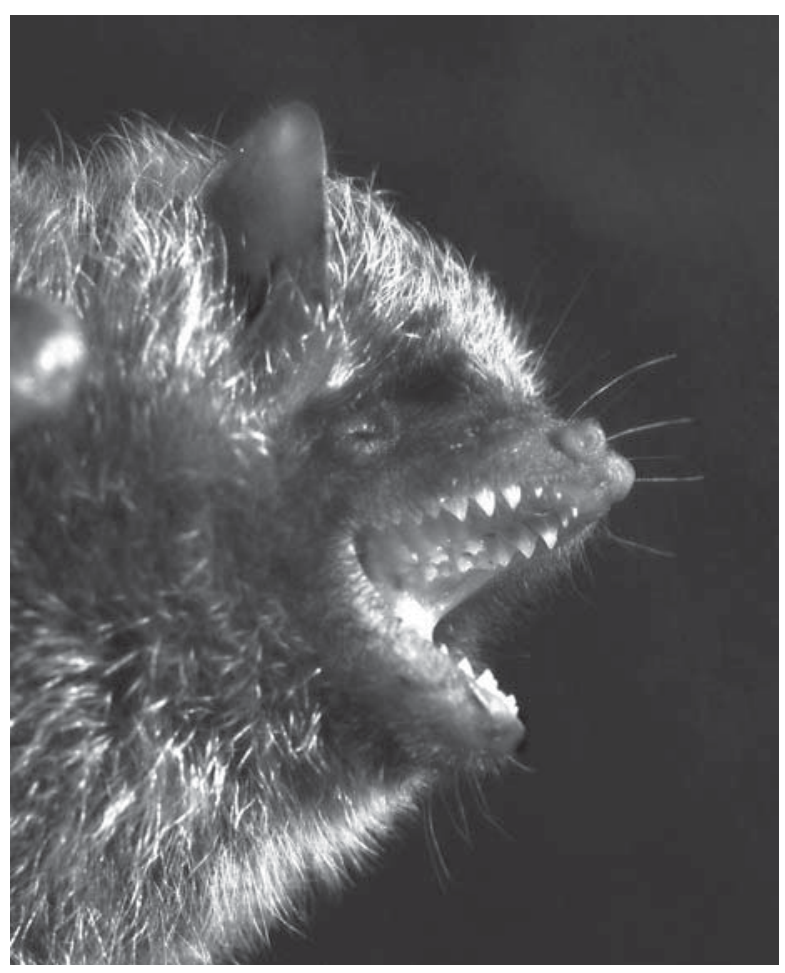

Figure 3. Subadult male of Harpiola isodon. Characteristic dental pattern is well seen.

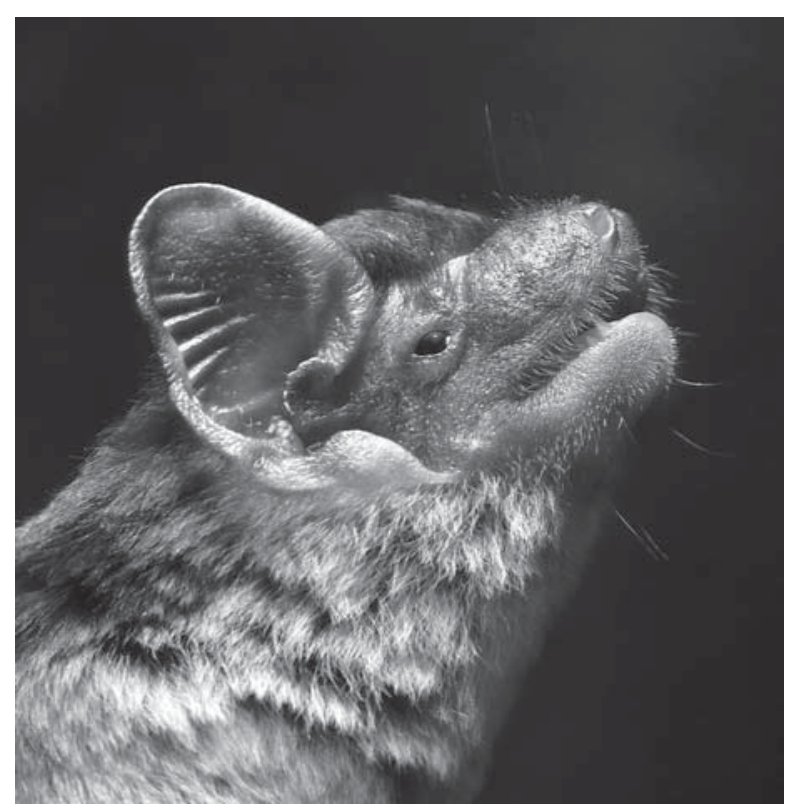

Figure 4. Adult male of Hypsugo cf. joffrei.

before sunrise) over the backwater of Suoi Vang stream below the waterfalls, at the elevation of ca. $1900 \mathrm{~m}$ a.s.l. on 11 May. Later, on 13 and 15 May, two other males of this species were captured in the same place. An adult female was captured on 17 May in the vicinity of Cat Cat village. Individuals supposedly of the same 
species were observed several times foraging and drinking in the valley of Suoi Vang Stream. In the vicinity of Cat Cat these bats were common, observed in the evening hours while foraging in a Nyctalus-like manner over the gorges and river valley, from several to tens of meters above the ground.

Eleven other bat species were captured in association with the above three. Single specimen of Thainycteris aureocollaris, Hypsugo cadornae and a small Murina sp., closely related or conspecific to Murina harpioloides from Dalat plateau, were captured at the same site above the waterfalls as Barbastella and Harpiola. Thainycteris aureocollaris and $H$. cadornae represent the only fifth and third records of the species from Vietnam, respectively. Rhinolophus affinis, Miniopterus fuliginosus, Myotis siligorensis, Myotis montivagus and Pipistrellus coromandra were captured and commonly observed in riverine habitats both upstream and downstream of the waterfalls. Aselliscus stoliczkanus, Rhinolophus macrotis and Murina huttoni were also captured over the small forest tributary of Suoi Vang. One additional species, Myotis laniger, was captured in the latter site in 2009 by the AVS, but was not observed in 2010.

At least two other bat species were observed in the same area but not confirmed by captured individuals. Relatively large fast-flying insectivorous bats with low frequency FM echolocation calls at about $12-15 \mathrm{kHz}$ were observed twice near the Tram Ton forest station. The flight pattern and echolocation calls resembled that of Molossidae and the large body size suggests that the observed bats could be Tadarida latochei or T. insign$i s$. These two species are known from south China and Laos close to Vietnamese border, but not recorded yet from Vietnam (Corbet \& Hill, 1992; Francis, 2008). Another observation was of a pteropodid bat flying between trees over the Suoi Vang Stream at early dusk on May 14. In general appearance and size the observed individual resembled Rousettus leschenaulti, a species known to inhabit relatively high elevations in other regions of Southeast Aisa (Csorba et al., 1999). If confirmed, this may be the highest latitude where a fruit bat has been observed in Vietnam.

\section{Discussion}

The systematic position of some of the newly recorded species is not absolutely clear and pending further confirmation from molecular data.

Specifically, the identity of bats mentioned above as Hypsugo cf. joffrei is quite problematic. Hypsugo joffrei has been known from only the small type series collected in Northern Burma (Corbet \& Hill, 1992). This species is supposed to be closely related (and morphologically very similar) to $H$. anthonyi, also from Burma which known by the type specimen only with damaged skull (Tate, 1942; Corbet \& Hill, 1992). Both species are of the same size with a forearm length of $c a$. $39 \mathrm{~mm}$. Their general body and wing shape resemble genus Nyctalus, to which they were sometimes allocated (Koopman, 1994), and also "Pipistrellus" stenopterus and Philetor brachypterus (Hill, 1966). Both P. joffrei and $P$. anthonyi are characterized by broad and short muzzle, broad tragi, narrow and pointed wing, short velvety fur, short and robust rostrum, very distinct and massive supraorbital projections, presence of small upper premolar though minute and displaced from tooth row, and supposedly by distinct secondary cusps on the posterior blades of the upper canines (Corbet \& Hill, 1992; Koopman, 1994; Francis, 2008). Two other "pipistrelles" of similar size presumably occurring in the region are Pipistrellus ceylonicus and Falsistrellus affinis. The former is a typical Pipistrellus in general proportions as well as in tooth structure and baculum shape. The latter differs from the joffrei/anthonyi complex by longer fur, wider wing, elongated braincase and less reduced upper small premolar (Francis, 2008). Finally, it is supposed that baculum of $H$. joffrei should be minute and delicate (Hill, 1966); baculum of $H$. anthonyi is not known.

Our specimens conform to all the described features of the joffrei/anthonyi group despite their slightly smaller size (forearm length is 35.7-38.6). They also have myotodont lower molars which put them apart from tribe Pipistrellini (including "Pipistrellus" stenopterus and Philetor brachypterus which are both nyctalodonts). The two species of the complex differ mainly by pelage coloration (Corbet \& Hill, 1992); based on this feature our specimens might be referred to as $H$. anthonyi which is more dark-colored of the two. However, we prefer to use the name of better known and better described species of this complex, $H$. joffrei, which is the type for the species group. External genitalia well conform that of $H$. joffrei as they were described by Hill (1966). Baculum of one dissected male is minute and delicate, about $1.1 \mathrm{~mm}$ in length. It has a narrow main shaft with slightly concave ventral surface and bluntly rounded tip, and widely expanding basal lateral projections, somewhat turned downward at their ends (Fig. 5). Thus this baculum shape obviously differs from the structure of those of "Pipistrellus" stenopterus or Philetor, and even more so from the penis bones of either Pipistrellus s.str. or Hypsugo (Hill \& Harrison, 1987) but bares some resemblance with those of some plecotines and Arielulus. Although presence of a reduced

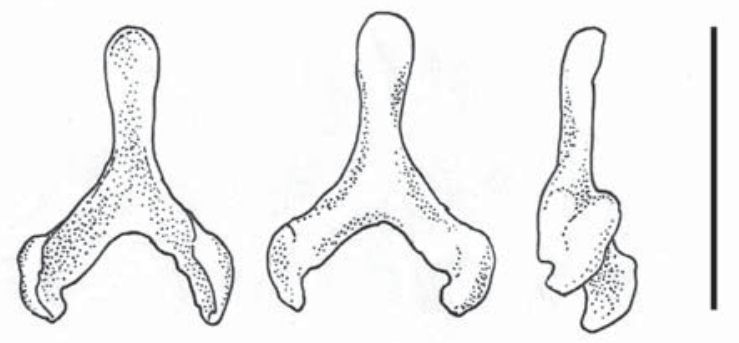

Figure 5. Baculum of Hypsugo cf. joffrei from Sa Pa: ventral, dorsal and lateral view.

Scale bar $=1 \mathrm{~mm}$. 
small upper premolar and myotodont lower molars in combination with some external features support the allocation of joffrei/anthonyi to Hypsugo, the baculum shape contradicts this view, calling for an in-depth taxonomic reassessment.

Barbastelles were not previously known from Vietnam. The taxonomic positoin of our specimens needs further examination, particularly in view of the recent notion that the genus Barbastella has a complex species structure. The forearm length in our individuals is 41.7 and 40.0, which corresponds well to both $B$. beijingensis and B. darjelingensis size limits (Zhang et al., 2007; Benda et al., 2008). According to cranial size estimated from canine width (3.75 and 3.94) Hoang Lien Son specimens are also more or less similar to B. darjelingensis and smaller than species from Central China. Our barbastelles possess very dark, almost black fur, tipped with brown and almost similar on back and ventral surface. Such coloration is much darker than that of $B$. darjelingensis from Central Asia and in one specimen from Nepalese Himalayas (S-164496 in collection of ZMMU), but similar to that of $B$. beijingensis (Zhang et al., 2007). Indian specimens of B. darjelingensis, according to their description (Bates \& Harrison, 1997; Chakraborty, 1983) also have blackish coloration, but with grayish tinges and with fur tipped with white, not brown. As in typical $B$. darjelingensis, individuals from Hoang Lien Son have straight posterior ear edges without any lobes. Until additional (e.g. from molecular genetics) data become available we tentatively refer barbastelles from Vietnam to $B$. darjelingensis, accepting that the northern Vietnamese highlands could be inhabited by a distinct subspecies.

The bat fauna of Hoang Lien Son contains a rich mix of species of different zoogeographic origin. Malayan faunal elements represented by Cynopterus sphinx, C. brachyotis, Harpiocephalus harpia and Tylonycteris pachypus are probably restricted in Hoang Lien Son to low elevations. The same is true for Hipposideros armiger, H. pomona and Coelops frithii though their distribution extends further northward into south China (Smith \& Xie, 2008) and, in the case of $H$. armiger, westward along the Himalayas mountain range (Bates \& Harrison, 1997). Kerivoula hardwickei, while predominantly Malayan in distribution, represents a complex of several genetically diverse lineages (Francis, 2008; Francis et al., 2007) and the proper affinities of Hoang Lien Son woolly bats need further clarification on the base of molecular data. Contrarily, Rousettus leschenaulti, Sphaerias blanfordi, Rhinolophus sinicus, Myotis montivagus, M. siligorensis, Scotomanes ornatus, Hypsugo cf. joffrei, Pipistrellus coromandra and possibly some other species have Indo-Himalayan origin and supposedly penetrate into Indochina from the north along mountain ranges. Barbastella darjelingensis is also an Indo-Himalayan species (Corbet \& Hill, 1992); however, the genus Barbastella on the whole is predominantly a Palaearctic taxon (Corbet, 1978; Koopman, 1994). Also Myotis chinensis could also be regarded as a Palaearctic faunal element. Despite the fact that most of its distribution is within the formal boundaries of South-East Asia (Corbet \& Hill, 1992), all related species (Zhang et al., 2009) obviously have Palaearctic distribution. Rhinolophus paradoxolophus, the closely related $R$. marshalli and probably Myotis laniger are specific to the mountainous regions of the northern Indochina and southern China. The distribution of Aselliscus stoliczkanus and Thainycteris aureocollaris is also confined mainly to mountainous areas of the northern Indochina (Dang Ngoc Can et al., 2008; Francis, 2008).

The distribution of Harpiola isodon represents an exceptional case. The new record in Hoang Lien Son is situated in-between two previously known localities, at about $1800 \mathrm{~km}$ from the species terra typica on Taiwan (Kuo et al., 2006), and about $930 \mathrm{~km}$ north from previously known Vietnamese record (Kruskop et al., 2006). Thus it can be supposed that present distribution represents remnants of a much wider former range and that there is a possibility to find further Harpiola localities. Somewhat similarly, Murina cf. harpioloides was previously known only from the Dalat Plateau (Abramov et al., 2010), whereas its closest plausible congener occurs in China (J. Eger, pers. comm.).

Summarizing we can consider that our recent results demonstrate that there is a considerable scope for bat research in Hoang Lien Son and in North Vietnam on the whole. Although the present field survey was restricted in time and space two species were added to the fauna of the country and two another were recorded for second time and represent large extensions in distribution. Aside from providing information on local bat assemblages critical for conservation planning, possible further investigation of this area will have important ramifications in our understanding of the history and origin of bat faunas in the northern and central Indochina.

ACKNOWLEDGMENTS. We are grateful to the administration of the Hoang Lien Son National Park for providing the opportunity to carry out the surveys in the Park. Our field studies in Vietnam were possible due to the support of the Joint Vietnam-Russian Tropical Research and Technological Centre. We would like to express our thanks to Dr. Nguyen Dang Hoi, Dr. A.N. Kuznetsov and Dr. V.V. Rozhnov for their administrative support of the studies, to Dr. A.V. Abramov for his help and scientific expertise during the field works. We appreciate Dr. M. Ruedi (Geneva, Switzerland), Dr. J. Eger (Toronto, Canada) and Dr. G. Csorba (Budapest, Hungary) for providing first author possibility to process the comparative scientific material; processing of the comparative material in Geneva was held under financial support of the grant provided by Natural History Museum of Geneva. Morphological study of the specimens was partially supported by RFBR grant \# 10-04-00683-a. 


\section{References}

Abramov A.V., Kruskop S.V. \& Schinov A.V. 2010. Small mammals of the Dalat Plateau, southern Vietnam // Russian Journal of Theriology. Vol.8 (for 2009). No.2. P.61-73.

Bates P.J.J. \& Harrison D.L. 1997. Bats of the Indian subcontinent. Sevenoaks: Harrison Zoological Museum. $258 \mathrm{p}$.

Benda P., Dietz C., Andreas M., Hotovy J., Lucan R.K., Maltby A., Meakin K., Truscott J. \& Vallo P. 2008. Bats (Mammalia: Chiroptera) of the Eastern Mediterranean and Middle East. Part 6. Bats of Sinai (Egypt) with some taxonomic, ecological and echolocation data on that fauna // Acta Societas Zoologicae Bohemicae. Vol.72. P.1103.

Borissenko A.V. \& Kruskop S.V. 2003. Bats of Vietnam and Adjacent Territories. An Identification Manual. Moscow: Geos. 203 p.

Bouret R. 1951. Une nouvellechauve-souris du Tonkin, Rhinomegalophus paradoxolophus // Bulletin du Muséum national d'Histoire naturelle Paris. Vol.33. P.607-609.

Chakraborty S. 1983. Contribution to the mammalian fauna of Jammu and Kashmir, India. Records of the Zoological Survey of India. Vol.38. P.1-129.

Corbet G.B. 1978. The Mammals of the Palaearctic Region: a Taxonomic Review. London \& Ithaca: Cornell University Press. 314 p.

Corbet G.B. \& Hill J.E. 1992. The Mammals of the Indomalayan Region. Oxford: Oxford University Press. 488 p.

Csorba G., Kruskop S.V. \& Borissenko A.V. 1999. Recent records of bats (Chiroptera) from Nepal, with remarks on their natural history // Mammalia. Vol.63. No.1. P.6178.

Dang Huy Huynh, Dao Van Tien, Cao Van Sung, Pham Trong Anh \& Hoang Minh Khien. 1994. [Checklist of Mammals in Vietnam]. Hanoi: Publishing House "Science \& Techniques". 168 p. [in Vietnamese].

Dang Ngoc Can, Endo H., Nguyen Truong Son, Oshida T., Le Xuan Canh, Dang Huy Phuong, Lunde D.P., Kawada S.-I., Hayashida A., Sasaki M. 2008. [Checklist of Wild Mammal Species of Vietnam]. Hanoi: Institute of Ecology and Biological Resources. 400 p. [in Vietnamese].

Francis C.M. 2008. A field guide to the mammals of SouthEast Asia. London: New Holland. 392 p.

Francis C.M., Kingston T. \& Zubaid A. 2007. A new species of Kerivoula (Chiroptera: Vespertilionidae) from peninsular Malaysia // Acta Chiropterologica. Vol.9. No.1. P.1-12.

Happold D.C.D. \& Happold M. 1990. Reproductive strategies of bats in Africa // Journal of Zoology. Vol.222. No.4. P.557-583.

Hendrichsen D.K., Bates P.J.J., Hayes B.D. \& Walston J.L. 2001. Recent records of bats (Mammalia: Chiroptera) from Vietnam with six species new to the country // Myotis. Vol.39. P.35-122.

Hill J.E. 1966. A review of the genus Philetor (Chiroptera: Vespertilionidae) // Bulletin of the British Museum Natural History (Zoology). Vol.14. P.371-387.

Hill J.E. \& Harrison D.L. 1987. The baculum in Vespertilioninae (Chiroptera: Vespertilionidae) with a systematic review, a synopsis of Pipistrellus and Eptesicus, and the description of a new genus and subgenus // Bulletin of the British Museum (Natural History), Zoology Series. Vol.52. No.7. P.225-305.

Hoffmann R.S. 2001. The southern boundary of the Palaearctic realm in China and adjacent countries // Acta Zoologica Sinica. Vol.47. No.2. P.121-131.

Koopman K.F. 1994. Chiroptera: Systematics // Neithammer J., Schliemann H., Starck D. (eds.). Handbook of Zoology. Mammalia. Berlin \& New York: Walter de Gruyter. Vol.8. Part 60. 217 p.

Kruskop S.V., Kalyakin M.V. \& Abramov A.V. 2006. First record of Harpiola (Chiroptera, Vespertilionidae) from Vietnam // Russian Journal of Theriology. Vol.5. No.1. P.15-18.

Kunz T.H. \& Kurta A. 1990. Capture methods and holding devices // Kunz T.H. (ed.). Ecological and behavioral methods for the study of bats. Washington \& London: Smithsonian Institution Press. P.1-29.

Kuo H.-C., Fang Y.-P., Csorba G. \& Lee L.L. 2006. The definition of Harpiola (Vespertilionidae: Murininae) and the description of a new species from Taiwan // Acta Chiropterologica. Vol.8. No.1. P.11-19.

Kuznetsov G.V. \& Rozhnov V.V. 1998. [Mammals of the mountain region of Sa Pa and Fan Si Pan: species diversity and problems of its conservation] // Korzun L.P. \& Kalyakin M.V. (eds.) [Materials of Zoological and Botanical Studies in the Fan Si Pan Mountain Massif (North Vietnam)]. Moskva - Khanoi. P.129-158 [in Russian].

Nguyen Truong Son, Dang Huy Phuong, Trinh Viet Cuong, Vu Dinh Thong, Csorba G. 2009. Preliminary results about bats and rodent in Vinh Cuu Nature Reserve and Historical Monument, Dong Nai province // Proceedings of the 3rd National Scientific Conference on Ecology and Biological Resources. Hanoi: Agricultural Publish House. P.776-783.

Osgood W.H. 1932. Mammals of the Kelley-Roosevelts and Delacour Asiatic expeditions // Publications of the Field Museum of Natural History, Zoology. Vol.18. P.193339.

Polet G. \& Ling S. 2004. Protecting mammal diversity: opportunities and constraints for pragmatic conservation management in Cat Tien National Park, Vietnam // Oryx. Vol.38. No.2. P.1-11.

Rozhnov V.V. 1998. [Natural history investigations in Indochina: historical review] // Korzun L.P. \& Kalyakin M.V. (eds.). [Materials of Zoological and Botanical Studies in the Fan Si Pan Mountain Massif (North Vietnam)]. Moskva-Khanoi. P.11-66 [in Russian].

Rozhnov V.V., Abramov A.V., Kuznetsov G.V. \& Morozov P.N. 2008. [Mammals of Hoang Lien Son] // [Biodiversity of Hoang Lien Son Mountains]. Hanoi: RussianVietnamese Tropical Center \& Hoang Lien National Park. P.80-103 [in Vietnamese].

Smith A.T. \& Xie Y. (eds.). 2008. A Guide to the Mammals of China. Princeton: Princeton University Press. 544 p.

Tate G.H.H. 1942. Review of the Vespertilionine bats, with special attention to genera and species of the Archbold collections // Bulletin of the American Museum of Natural History. Vol.80. No.7. P.221-297. 
Tordoff A., Swan S., Grindley M. \& Siurua H. 1999. Hoang Lien Nature Reserve. Frontier- Vietnam Forest Research Programme. Unpublished report No.13. London: Society for Environmental Exploration. 86 p.

Zhang J.-S., Han N.-J., Jones G., Lin L.-K., Zhang J.-P., Guan-Jian Z., Huang D.-W. \& Zhang S.-Y. 2007. A new species of Barbastella (Chiroptera: Vespertilionidae) from
North China // Journal of Mammalogy. Vol.88. No.6. P.1393-1403.

Zhang Z., Tan X., Sun K., Liu S., Xu L. \& Feng J. 2009. Molecular systematics of the Chinese Myotis (Chiroptera, Vespertilionidae) inferred from cytochrome-b sequences // Mammalia. Vol.73. P.323-330. 